\title{
MUTU PELAYANAN BIDAN PRAKTEK MANDIRI KOTA SURABAYA
}

\author{
Indria Nuraini \\ Magister Kedokteran Keluarga Program PASCASARJANA UNS
}

\begin{abstract}
Background: From year to year in the Independent Practice Midwife Surabaya City has experienced an increase in health care with the Bidan Delima. But all this is not enough if there are many important aspects that have not been improved, such as hospitality midwife and the midwife are less communicative with patients and tackle these and slow in decision making in emergencies.

Objective: To determine the quality of health care in Independent Practice Midwife Surabaya City.

Methods: The design used was descriptive qualitative with case study a stuck strategy. The subjects of this study were all Independent Practice Midwife in Surabaya and retrieved using purposive sampling technique. The process of data retrieval was done by in-depth interviews. Confidence data test consists of the credibility and transferability test, while the data analysis using inductive thinking process.

Results: The quality of services provided by BPM has met the four dimensions of quality of service properly, that is reliability, responsiveness, empathy and assurance, while the tangible dimension still need improvement. Services in BPM is fast, precise and midwives are very friendly and very caring towards his clients. The entire informants were satisfied and midwife services are perceived better than hospital services. The hope from informant, BPM can improve support facilities such as parking and air conditioning. In addition to the equipment used by all midwives studied were standard and no modifications.
\end{abstract}

Suggestion: For independently practice midwfeexpected to develop the quality of services, especially the provision of means of support so as to improve the competitiveness of BPM

Keyword :Independently practice midwife, Quality service 


\section{PENDAHULUAN}

\begin{abstract}
Kesehatan merupakan hak asasi manusia dan hal tersebut merupakan salah satu unsur kesejahteraan yang harus diwujudkan sesuai dengan cita - cita bangsa indonesia sebagaimana dimaksud dalam Pancasila dan Undang - Undang
\end{abstract} Dasar Negara Republik Indonesia Tahun 1945. Untuk mewujudkan hal tersebut, diselenggarakan upaya kesehatan yang terpadu dan menyeluruh dalam bentuk upaya kesehatan perseorangan dan upaya kesehatan masyarakat, dengan pendekatan promotif, preventif, kuratif, dan rehabilitatif yang dilaksanakan secara terpadu, menyeluruh, dan berkesinambunga. (Undang - Undang No 36 tahun 2009) Untuk mendukung upaya kesehatan maka diperlukan Tenaga Kesehatan yang bertugas melakukan kegiatan pelayanan kesehatan yang berkualitas sesuai dengan bidang keahlian dan kewenangannya. Bidan adalah salah satu kategori tenaga kesehatan yang dapat berperan serta dalam upaya mewujudkan pencapaian derajat kesehatan masyarakat yang optimal khususnya kesejahteraan ibu dan anak, hal ini sejalan dengan pencapaian Millenium Development Goals (MDGs). Salah satu target MDGs adalah menurunkan angka kematian ibu saat melahirkan. Angka kematian ibu di Indonesia masih cukup tinggi yaitu 228/100.000 kelahiran (2007), sedangkan target MDGs 2015 yaitu 102/100.000 kelahiran. Angka Kematian Ibu dijawa Timur mencapai 97,4/100.000 kelahiran pada tahun 2012 mengalami penurunan dari 104,4/100.000 pada tahun 2011, akan tetapi angka kematian ibu disurabaya tertinggi kedua yaitu 60/41.481 tahun 2012 meskipun surabaya tersedia fasilitas kesehatan yang memadai. Angka kematian ibu banyak disebabkan karena eklampsia/preeklampsi berat, perdarahan 
post partum, penyakit jantung dan penyakit kronis. (Dinas Kesehatan Kota Surabaya, 2013)

Tingginya Angka Kematian Ibu (AKI) di kota Surabaya disebabkan oleh kurang optimalnya pelayanan kesehatan dalam pertolongan persalinan oleh tenaga kesehatan, komplikasi kebidanan yang ditangani oleh dokter atau bidan dan pelayanan rujukan ibu resiko tinggi.

Pada akhir-akhir ini terlihat bahwa Bidan Praktek Mandiri (BPM) terus berkembang, baik dalam jumlah, kapasitas maupun sarana prasarana seiring dengan perkembangan tehnologi. Walaupun terdapat perkembangan Bidan Praktek Mandiri (BPM) dari waktu ke waktu, tetapi fungsi dasar suatu Bidan Praktek Mandiri (BPM) tetap tidak berubah. Fungsi dasar Bidan Praktek Mandiri (BPM) adalah Pelayanan Kesehatan pada Ibu dan Anak, yang meliputi pemeriksaan kehamilan, pertolongan persalinan, imunisasi dan KB. Bidan Praktek Mandiri merupakan suatu tempat pelayanan, yang menyelenggarakan pelayanan medik untuk Kesehatan Ibu dan Anak (Kuncoro,2000) 
Mutu pelayanan Kesehatan dapat dilihat dari tingkat BOR (Bed Occupancy Rate) dan ALOS (Average Length of Stay) yang dicapai, serta tingkat kepuasan pasien atas pelayanan yang didapatkan.(Mas'ud,2004).

Bidan Praktek Mandiri merupakan usaha pelayanan jasa kesehatan yang salah satunya berdasar pada azas kepercayaan sehingga masalah kualitas pelayanan, kepuasan Pasien dan Loyalitas Pasien menjadi faktor yang sangat menentukan keberhasilannya. Kualitas pelayanan akan dihasilkan oleh operasi yang dilakukan dan keberhasilan proses operasi ini ditentukan oleh beberapa faktor antara lain; faktor karyawan, sistem, teknologi dan keterlibatan pelanggan yang diharapkan memberikan kontribusi terhadap kualitas pelayanan yang tercipta (Tjiptono,2000).

Pelayanan yang berkualitas harus memenuhi lima dimensi yaitu : tangibles (penampilan), realibility (kehandalan), responsiveness (ketanggapan), assurance (kepastian) dan emphaty (empati). (Iqbal,2006)

Bidan Praktek Mandiri di kota surabaya selalu berupaya terus untuk dapat meningkatkan pelayanan guna memuaskan pasien dan membangun kesetiaannya. Faktor-faktor yang mempengaruhi loyalitas pasien adalah kepuasan hidup dan tempat strategis Bidan Praktek Mandiri. Semakin banyaknya pilihan bagi konsumen dalam memilih suatu Bidan Tempat Praktek (BPM), maka semakin ketat persaingan dalam memenangkanya. Dari tahun ke tahun Bidan Praktek Mandiri dikota surabaya sudah mengalami peningkatan pelayanan kesehatan dengan adanya bidan delima. Dari 316 BPM dikota surabaya terdapat 154 bidan delima. Selain itu sering diadakannya pelatihan, seminar, work shop. Tetapi semua ini tidak cukup jika masih banyak aspek yang penting yang belum ditingkatkan, seperti keramahan bidan, serta kurang komunikatifnya antara bidan dengan pasien dan lambannya dalam menanggani dan pengambilan keputusan pada kegawatdaruratan. Tujuan dari penelitian ini adalah untuk 1) Mengidentifikasi standar pelayanan kebidanan di Bidan Praktek Mandiri; 2) Mengidentifikasi pelaksanaan pelayanan kesehatan di Bidan Praktek Mandiri; 3) Mengidentifikasi persepsi pasien tentang pelayanan kesehatan di Bidan Praktek Mandiri. 


\section{METODE PENELITIAN}

Penelitian ini dilaksanakan di Bidan Praktek Mandiri di Kota Surabaya pada bulan Oktober 2013. Desain penelitian ini adalah deskriptif kualitatif dengan strategi studi kasus terpancang. Sumber data penelitian berasal dari hasil wawancara dengan informan, observasi dan dokumentasi.Subyek dalma penelitian ini adalah semua Bidan Praktek Mandiri di Kota Surabaya dan diambil menggunakan teknik purposive sampling. Proses pengambilan data dilakukan dengan metode wawancara mendalam, proses pengambilannya informan diberi beberapa pertanyaan oleh peneliti dan hasil jawaban informan langsung direkam kedalam tape recorder, dan untuk pengambilan gambar informan menggunakan kamera digital (dengan sepengetahuan informan), hasil dari semua jawaban informan juga dirangkum. Uji keperacayaan data terdiri dari uji kredibilitas serta uji transferability, sedangkan teknik analisa data menggunakan proses berpikir induktif

TEMUAN PENELITIAN DAN

PEMBAHASAN
Penelitian dilakukan dengan wawancara kepada informan yang merupakan pasien dari 3 BPM di Kota Surabaya, untuk triangulasi dilakukan dengan menggunakan triangulasi sumber dan observasi langsung pada kondisi pelayanan kebidanan di 3 BPM tersebut. Standar Pelayanan Kebidanan Pada Bidan Praktek Mandiri Terkait dengan standar pelayanan kebidanan pada Bidan Praktek Mandiri pada umumnya semua informan memberikan tanggapan tentang jenis pelayanan sesuai dengan tugas pokok dan fungsi bidan sesuai dengan Permenkes Nomor1464/Menkes/Per/X/2010 tentang izin Praktek Bidan. Jenis pelayanan yang diberikan oleh BPM di Kota Surabaya menurut Informan adalah: $\mathrm{KB}$, pemeriksaan kehamilan, persalinan, imunisasi, periksa anak sakit (diare, batuk \& pilek) dan Uap bayi \& balita" Informan 3.

Berdasarkan keterangan para informan tersebut kemudian dikonfirmasikan kepada masing- masing bidan di BPM, dan diperoleh hasil sebagai berikut:

Sudah sesuai dengan aturan/program dari IBI, hal ini dibuktikan dengan adanya sertifikat Bidan Delima" Bidan 3"' 
Berdasarkan keterangan yang diberikan

oleh informan diketahui bahwa seluruh

BPM memberikan pelayanan sesuai

dengan jenis pelayanan yang menjadi

wewenang bidan, tetapi dalam

pelaksanaannya tidak harus sesuai

dengan standar operasional yang

diberikan oleh PB IBI sebagai acuan

bagi bidan dalam memberikan pelayanan

seperti yang dinyatakan oleh pihak

Bidan. Tentang standar pelayanan,

informan memberikan keterangan

sebagai berikut

Belum semuanya sesuai standar. Ini terlihat setiap tindakan yang dilakukan selalu di informasikan terlebih dahulu dan selalu memberikan penyuluhan setiap selesai tindakan. (seperti : dijelaskan posisi bayinya, diberikan penyuluhan tentang nutrisi untuk ibu hamil, cara minum tablet tambah darah) tetapi masih ada hal yang penting tidak dilakukan seperti: pemeriksaan laboratorium Untuk darah dan urin. Bidan menganggap bahwa dengan pemeriksaan fisik saja sudah cukup" Informan 4"

Pelaksanaan Pelayanan Kesehatan

Pada Bidan Praktek Mandiri

Pelaksanaan pelayanan kesehatan pada BPM diuji dari dimensi mutu

pelayanan, terkait dengan dimensi

reliability dan responsiveness,

informan memberikan respon

terhadap pertanyaan yang diberikan

terkait dengan daya tanggap bidan

dalam memberikan pelayanan, dan

jawaban informan adalah sebagai

berikut

Pelayanannya cepat (Waktu tunggu yang tidak lama) dan bidannya tanggap (jika ada kegawat daruratan penanganannya cepat, dan tepat dalam menentukan diagnosa/masalah, tindakan ataupun rujukan). Serta setiap control selalu diberi vitamin yang berbeda - beda dan katanya vitamin yang diberikan adalah yang paling bagus." Informan 4"'

Sedangkan terkait dengan dimensi

empathy masing-masing informan

memberikan pernyataan sebagai berikut

Bidannya ramah dan sangat memperhatikan kebutuhan kliennya serta sangat sabar sekali. Karena kesabaran bidannya Kami sekeluarga selalu melahirkan di BPM" Informan 1"

Jawaban informan terkait dengan

pelayanan BPM pada dimensi tangible

yang dikaitkan dengan kelengkapan 
sarana dan prasarana yang diberikan oelh

BPM diperoleh jawaban sebagai berikut

"Tidak semuanya, tempatnya bersih tetapi tidak ada tempat parkir yang memadai serta ruang tunggu yang panas" Informan 3

"Tempatnya bersih dan nyaman tetapi tidak ada tempat parkir yang memadai” Informan 6

Berdasarkan keterangan informan tersebut diketahui bahwa BPM dalam memberikan pelayanan telah memiliki daya tanggap yang cukup baik, serta reliabel dan empati yang ditunjukkan oleh bidan merupakan kekuatan dari pelayanan yang diberikan oleh BPM, sedangkan dari sisi sarana dan pra sarana (dimensi tangible), masih terdapat kekurangan yaitu kenyamanan ruang tunggu dan sarana parkir.

Evaluasi yang diberikan oleh IBI pada saat monitoring bagi bidan disikapi sebagai masukan untuk perbaikan mutu pelayanan yang diberikan BPM Keterangan dari Informan dan BPM tersebut dapat disimpulkan bahwa mutu pelayanan yang diberikan oleh BPM telah memenuhi 4 dimensi mutu layanan dengan baik yaitu reliability, responsiveness, empathy dan assurance, sedangkan pada dimensi tangible masih membutuhkan perbaikan.

Persepsi Pasien Terhadap Pelayanan Kesehatan Pada Bidan Praktek Mandiri

Muara pelayanan kesehatan yang diberikan oleh BPM adalah munculnya persepsi positif dari pasien yang merupakan konsumen BPM, sehingga dapat meningkatkan loyalitas pasien dan menjadi daya dukung yang positif bagi BPM untuk mengembangkan pemasarannya. Persepsi yang diberikan oleh pasien terkait dengan pelayanan yang telah diberikan bidan adalah sebagai berikut

\footnotetext{
"rata - rata pasien puas dengan pelayanan yang diberikan dapat terlihat dari jumlah kunjungan terus meningkat, seperti : suntik KB, periksa kehamilan, imunisasi serta persalinan" Informan 2
} 


\section{"Iya, dengan kualitas terbaik seperti pelayanannya cepat, tepat dan bidannya sangat ramah serta sangat peduli dengan kliennya" Informan 6}

Persepsi pasien terhadap pelayanan yang diberikan oleh bidan diketahui bahwa:

"Saya merasa puas dengan semua pelayanan yang diberikan BPM atau bisa dikatakan pelayanan BPM lebih baik daripada di rumah sakit" Informan 3

Berdasarkan persepsi pasien tersebut, pasien memberikan saran kepada bidan sebagai berikut :

"Ditingkatkan pelayanannya dan saya berharap agar disediakan tempat untuk parkir dan ruang tunggunya diberi $\mathrm{AC}$ atau kipas angin" Informan 4

Persepsi pasien secara umum pasien

sudah cukup puas dengan pelayanan

yang diberikan oleh BPM namun pasien

masih merasa ada kekurangan dalam

pelayanan yang diberikan oleh bidan

diantaranya adalah masalah suhu ruangan dan parkir kendaraan. Terkait dengan

masukan dari pasien, bidan menyatakan

"Ada, komplain masalah ruangan yang panas" Bidan 2

Berdasarkan keterangan yang diberikan oleh informan dan bidan dapat disimpulkan bahwa pelayanan di BPM cepat, tepat dan bidan sangat ramah serta sangat peduli terhadap kliennya. Seluruh informan merasa puas, dan pelayanan bidan dipersepsikan lebih baik daripada pelayanan di rumah sakit. Harapan informan, BPM dapat meningkatkan sarana pendukung seperti parkir dan pendingin ruangan.

\section{Pembahasan}

\section{Standar Pelayanan Kebidanan}

Pada Bidan Praktek Mandiri

Jenis pelayanan yang diberikan oleh semua $\mathrm{BPM}: \mathrm{KB}$, pemeriksaan kehamilan, persalinan, imunisasi, periksa anak sakit (diare, batuk \& pilek). Pelayanan laboratorium yang diberikan : 
Uji HB menggunakan Test Pack dan Hb

Sahli, Tes Kehamilan Menggunakan Test

Pack dan Tes HIV sesuai dengan standar.

Pelayanan yang diberikan oleh bidan

sudah sesuai dengan standar, diawali

dengan pemberian informasi dan diakhiri

dengan pemberian penyuluhan. Semua

bidan melakukan SOP dari IBI dan

tidak ada SOP khusus. Peralatan yang

dipergunakan oleh semua bidan yang

diteliti adalah standar dan tidak ada

modifikasi.

Bidan sebagai tenaga kesehatan yang

memiliki wewenang untuk memberikan

tindakan dalam pelayanan kesehatan ibu

dan anak dituntut untuk dapat

menerapkan standar yang ketat dalam

memberikan pelayanan, namun

penerapan standar yang ketat tersebut

sering berbenturan dengan kenyataan di

lapangan yang menuntut bidan untuk

melaksanakan improvisasi, kondisi ini

terkesan kontradiktif namun demi

keselamatan pasien seringkali bidan sedikit menyimpang dari standar asuhan kebidanan yang ditetapkan. Walaupun sebenarnya dalam memberikan pelayanan kebidanan, bidan harus mampu menerapkan pelayanan ibu hamil, bersalin dan nifas, yang berorientasi pada penerapan kode etik dan standar pelayanan kebidanan, serta kepuasan yang mengacu pada penerapan semua persyaratan pelayanan kebidanan. Dari dimensi mutu pelayanan kebidanan tersebut, tujuan akhirnya adalah kepuasan pasien yang dilayani oleh bidan.

Hal ini sesuai dengan Permenkes No. 900/SK/VII/2002 yang menyebutkan bahwa bidan memiliki wewenang untuk memberikan pelayanan kebidanan yang meliputi: pelayanan pranikah, kehamilan, persalinan, nifas, bayi baru lahir dan balita (Syafrudin, 2009).

Modifikasi standar asuhan kebidanan juga ditemukan dalam penelitian yang dilaksanakan oleh Sari (2007) 


menunjukkan bahwa dalam
melaksanakan asuhan kebidanan, bidan
berusaha sesuai dengan standar
pelayanan kebidanan yang telah
ditetapkan, namun kadang kala ada
hal-hal yang tidak tercantum dalam
standar asuhan sehingga membutuhkan
improvisasi Pelayanan kesehatan (medis)
termasuk praktik bidan merupakan hal
yang penting yang harus dijaga maupun
ditingkatkan kualitasnya sesuai standar
pelayanan yang berlaku, agar
masyarakat sebagai


dari bidan untuk melakukan tindakan dengan tujuan akhir menyelamatkan pasien, konsumen dapat merasakan pelayanan yang diberikan. Pelayanan sendiri hakikatnya merupakan suatu usaha yang membantu menyiapkan segala sesuatu yang diperlukan orang lain serta dapat memberikan kepuasan sesuai dengan keinginan yang diharapkan oleh konsumen dan supaya tidak terjadi kasus malpraktik.

Menurut penelitian yang dilakukan oleh Jennings (2011) di 5 negara berkembang menyatakan $77,2 \%$ melaksanakan tugas sesuai dengan wewenang yang diberikan oleh masing-masing negara, dan 22,8\% tidak patuh melaksanakan SOP disebabkan karena keadaan yang memaksa. Pada dasarnya bidan berusaha patuh dalam melaksanakan standar pelayanan, munculnya modifikasi dari standar pelayanan yang diberikan karena kondisi yang memaksa, dan di Indonesia hal ini diperbolehkan selama kondisi yang dihadapi merupakan keadaan yang memaksa misalnya mengancam jiwa pasien, tetapi dalam penelitian ini tidak terungkap penyimpangan tersebut.

Hal ini sesuai dengan Permenkes Nomor900/SK/MENKES/VII/2002

tentang Regristasi dan Praktek Bidan, pada pasal 21 disebutkan bahwa (1) Dalam keadaan darurat bidan berwenang melakukan pelayanan kebidanan selain kewenangan sebagaimana dimaksud dalam Pasal 14; (2) Pelayanan sebagaimana dimaksud pada ayat (1) ditujukan untuk penyelamatan jiwa.

Kendala yang dihadapi oleh bidan di Indonesia cukup komplek dimana pada bidan di pedesaan jarak antara BPM dengan lokasi rujukan terdekat cukup jauh, namun pada bidan di daerah perkotaan misalnya Surabaya, walaupun jarak tempat praktek dengan lokasi rujukan berdekatan namun karena lalu lintas macet waktu tempuhnya menjadi lama. Kondisi ini mendorong bidan untuk berimprovisasi sesuai dengan kebutuhan dengan tujuan 
utama untuk menyelamatkan pasien. wewenang atau memaksakan pasien untuk Kondisi inilah yang dialami oleh periksa di dokter tetapi memunculkan sebagian besar BPM di Kota Surabaya ketidak puasan pada pasien. Permasalahan sehingga walaupun berada di daerah ini disiasati dengan tetap melakukan perkotaan, improvisasi bidan sesuai dengan pengalaman bidan tetap diperlukan agar pasien dapat selamat saat dalam perawatan bidan. Bagi pasien standar pelayanan kebidanan sebenarnya tidak terlalu bepengaruh, karena prinsip utama pasien adalah mendapatkan pelayanan yang sebaik mungkin dan kondisi pasien tetap terjaga. Kondisi ini tercermin adanya beberapa pasien yang memiliki penyakit yang perawatannya membutuhkan perlakuan khusus di luar wewenang dan kompetensi yang dimiliki oleh bidan, tetapi tetap memaksa untuk mendapatkan pelayanan dari bidan dengan alasan biaya yang dikeluarkan jauh lebih murah daripada pemeriksaan yang diberikan oleh pihak rumah sakit maupun dokter praktek. Pada kondisi ini bidan menghadapi dilema antara melayani permintaan pasien tetapi harus melanggar pemeriksaan dasar pada pasien dan kemudian memberikan rujukan kepada pasien untuk melakukan pengobatan atau perawatan di rumah sakit. Sebagian besar masyarakat masih memandang bidan memiliki wewenang seperti halnya dokter yang secara khusus ditugaskan oleh negara untuk memberikan pelayanan kesehatan berbiaya rendah. Persepsi ini tetap ada walaupun di kota sebesar Surabaya. Hal ini tidak terlepas dari kebiasaan turun temurun ketika jumlah dokter masih terbatas dan batas-batas wewenang yang dimiliki oleh bidan belum didefinisikan dengan jelas dimana bidan pada masamasa tersebut melaksanakan tugas bukan hanya terbatas pada pelayanan KIA tetapi juga seluruh jenis pelayanan kesehatan yang dimungkinkan.

Kebiasaan masyarakat tersebut terbawa sampai dengan saat ini dimana ketika 
layanan pemeriksaan oleh tenaga dokter praktek sudah cukup banyak dan jumlah rumah sakit semakin banyak. Kehadiran bidan yang sebenarnya sebagai tenaga kesehatan yang memiliki wewenang hanya pada pelayanan kesehatan fisiologis pada ibu dan anak, oleh masyarakat bidan dipaksa untuk menjalankan peran dokter, bahkan pada bidan tertentu dikenal dapat menyembuhkan beberapa penyakit sehingga pasien bidan tersebut sangat banyak untuk mendapatkan pemeriksaan dan pengobatan. Padahal dalam tugas pokok dan fungsinya, bidan tidak emmiliki wewenang untuk melakukan pengobatan kecuali dengan memberikan obat bebas. Kondisi inilah yang menyebabkan bidan menyiasati kondisi ini dengan memberikan obat bebas untuk pengobatan dan tetap melakukan rujukan kepada pasien yang mengalami permasalahan beresiko.

Berbagai keadaan inilah yang mendorong bidan dalam memberikan pelayanan kesehatan di masyarakat tidak hanya berpedoman kepada standar asuhan kebidanan yang telah ditetapkan, namun juga memperhatikan kondisi psikologis masyarakat dan tingkat kepercayaan kepada bidan, namun pada sisi satunya bidan tetap dituntut untuk melaksanakan pelayanan kesehatan sesuai dengan wewenang yang dimilikinya.

\section{Pelaksanaan Pelayanan Kesehatan}

\section{Pada Bidan Praktek Mandiri}

Mutu pelayanan yang diberikan oleh BPM telah memenuhi 4 dimensi mutu layanan dengan baik yaitu reliability, responsiveness, empathy dan assurance, sedangkan pada dimensi tangible masih membutuhkan perbaikan.

Mutu pelayanan kebidanan yang diberikan oleh BPM dalam penelitian ini diukur dari sudut pandang pasien, karena pasienlah yang merasakan apa yang telah diberikan oleh bidan dalam memberikan pelayanan, selain diukur dari pendapat pasien, untuk mengukur dimensi assurance 
diukur dari kontrol kualitas pelayanan yang dilakukan oleh induk organisasi bidan dalam hal ini adalah IBI Cabang Kota Surabaya.

Teori yang dapat menjelaskan bagaimana kepuasan konsumen terbentuk adalah terpenuhinya kebutuhan yang diinginkan yang diperoleh dari pengalaman melakukan sesuatu, pekerjaan, atau memperoleh perlakuan tertentu dan memperoleh sesuatu sesuai kebutuhan yang diinginkan (Rodiah, 2009). Kualitas pelayanan bukti fisik dari suatu pemasaran jasa, sangat ditentukan bukti fisik berupa penggunaan alat, ketersediaan perlengkapan yang terpenuhi dan kemampuan individu dari aspek pemasaran untuk memberikan suatu kualitas pelayanan yang dapat memuaskan konsumen. Selain bukti fisik, klien juga menganggap bahwa bahwa kesopanan, keramahan dan perhatian petugas sangatlah penting karena dengan hal tersebut klien merasa dihargai. Perasaan dihargai akan memberikan kebahagian dan kepuasan bagi pelanggan, yang pada akhirnya dapat membangun loyalitas mereka terhadap produk/ jasa yang diberikan oleh BPM.

Prosedur pelayanan yang memudahkan dan cepat merupakan hal yang penting dalam pelayanan jasa. Kemudahan dalam mendapatkan pelayanan jasa merupakan salah satu komponen yang dapat mendorong kepuasan pasien. System pelayanan yang efektif meliputi metode dan prosedur untuk memenuhi kebutuhan pelanggan secara cepat, merupakan salah satu factor yang harus diperhatikan dalam konsep manajemen jasa pelayanan kesehatan. Penialaian baik yang diberikan oleh sebagian informan terhadap pelayanan kebidanan khususnya pada dimensi Empathy berdasarkan pemikiran responden, terutama dengan membandingkan kenyataan dengan harapan yang dimilikinya. Selain itu kondisi masyarakat yang datang untuk datang ke BPM biasanya tidak memiliki ekspektasi yang terlalu tinggi karena ratarata berasal dari golongan menengah ke 
bawah, menyebabkan harapan yang dimiliki tidak terlalu tinggi dalam artian keinginan informan mendapatkan pelayanan tidak terlalu muluk-muluk misalnya pasien tidak berharap pelayanan yang diberikan sampai 24 jam. Karena harapan yang dimiliki tidak terlalu tinggi selain itu juga peran petugas yang dianggap sudah cukup ramah dan peduli akan keluhan pasien maka pasien dapat dengan mudah dipuaskan sehingga dalam memberikan penilaian terhadap pelayanan sudah dianggap baik.

Menurut penelitian Windari (2012) terungkap bahwa bidan praktek mandiri memiliki empati yang besar kepada pasien. Kondisi ini tidak terlepas dari posisi bidan selain sebagai pengelola BPM, tetapi juga menjadi Bidan di Desa pada keluarahan tempat tinggal bidan, sehingga bidan cukup sering beinteraksi dengan pasiennya, hal ini memberikan dampak pada munculnya personal relationship antara bidan dengan pasien. Kuatnya hubungan antara bidan dengan pasien yang telah terjalin lama ini menjadikan posisi bidan di masyarakat cukup disegani dan dihormati. Manfaat dari kondisi ini adalah dalam memberikan pelayanan kepada pasien mudah untuk mendapatkan kepercayaan pasien dan pasien cenderung lebih terbuka sehingga permasalahan yang sedang dihadapi oleh pasien dapat diketahui dengan segera dan dicarikan solusinya. Kondisi yang berbda akan dihadapi oleh tenaga kesehatan yang baru mengenal pasien dimana pasien cenderung lebih tertutup dan menimbulkan kesulitan dalam melaksanakan anamnesa, kondisi inilah yang mendorong ada beberapa informan yang membandingkan bahwa bidan lebih baik dibandingkan dengan tenaga kesehatan lainnya.

Penelitian Hunnington (2011) mengungkapkan bahwa kelebihan bidan dibandingkan dengan tenaga kesehatan lain adalah kedekatannya dengan pasien. Dalam masyarakat di sebuah keluarahan, bidan memiliki dua peran, selain sebagai tenaga kesehatan, juga memiliki peran 
sebagai tokoh masyarakat sekaligus aparat yang bertanggung jawab terhadap jalannya sebuah program kesehatan pada sebuah kelurahan. Hal ini memberikan manfaat bagi bidan dan sekaligus masyarakat, karena bidan dan pasien sering berinteraksi dalam nuansa yang tidak formal mendorong pasien dapat mempercayakan informasi yang dianggap memalukan misalnya jika pasien mengalami PMS dapat mengungkapkan keluhannya kepada bidan secara mendetail. Didorong oleh posisi sebagai tokoh masyarakat maka bidan dapat dengan bijaksana menanggapi keluhan tersebut secara bijaksana, serta dapat mengambil tindakan yang tepat pula misalnya dengan melakukan rujukan. Sesuai dengan hasil penelitian ini dan penelitian sebelumnya teruangkap bahwa BPM memiliki kekuatan di dimensi empati dan hal ini mendorong pada pelayanan yang lebih baik pada daya tanggap dan kehandalannya, namun masih lemah pada segi sarana pendukung yang dimiliki.

\section{Persepsi Pasien Terhadap Pelayanan Kesehatan Pada Bidan Praktek Mandiri}

Pelayanan di BPM cepat, tepat dan bidan sangat ramah serta sangat peduli terhadap kliennya. Seluruh informan merasa puas, dan pelayanan bidan dipersepsikan lebih baik daripada pelayanan di rumah sakit. Harapan informan, BPM dapat meningkatkan sarana pendukung seperti parkir dan pendingin ruangan.

Penelitian yang dilakukan oleh Budiardja (2009) menunjukkan bahwa adanya hubungan antara empati petugas dalam berkomunikasi dengan kepuasan pasien. Penelitan yang dilakukan oleh Santoso (2004), juga menunjukkan hal yang sama yaitu dimensi empati pada mutu layanan memberikan pengaruh yang signifikan terhadap mutu layanan.

Hasil penelitian tersebut sama dengan hasil penelitian ini. Dalam penelitian sebelumnya empati petugas dalam 
melakukan komunikasi dapat mendorong dan memotivasi pasien sehingga pasien merasa diperhatikan dan pada akhirnya memunculkan kepuasan pada pasien. Kondisi sejalan dengan hasil penelitian yang dilakukan yang menunjukkan bahwa empati bidan dapat memberikan dorongan yang cukup signifikan kepada munculnya rasa puas pada pasien. Rasa empati yang ditunjukkan oleh bidan merupakan bentuk penghormatan dan rasa kekeluargaan kepada pasien dalam proses pelayanan kesehatan, kondisi ini menimbulkan rasa nyaman kepada pasien sehingga pasien terdorong untuk melaksanakan terapi secara patuh. Pengaruh yang diberikan oleh empati petugas tersebut tidak serta merta meningkatkan kepuasan pasien, karena ada informan yang mengungkapkan dirinya tidak puas terhadap fasilitas yang disediakan oleh BPM misalnya parkir kendaraan dan pendingin.

Kekuatan empati yang diberikan oleh bidan bahkan memberikan penilaian oleh seluruh informan bahwa pelayanan di BPM lebih baik dibandingkan dengan pelayanan di rumah sakit. Kondisi ini tidak terlepas dari kondisi pasien yang sedang mengalami permasalahan kesehatan sehingga sangat membutuhkan perhatian dari para pemberi pelayanan kesehatan, di rumah sakit dengan beban kerja yang tinggi, bidan atau perawat cenderung untuk bekerja secara praktis dan kurang berbasa- basi, kondisi inilah membuat sudut pandang informan terpengaruh bahwa pelayanan di BPM lebih baik dari pada pelayanan di rumah sakit, walaupun di rumah sakit peralatan yang disediakan cukup banyak.

Harapan atas kinerja produk berlaku sebagai standar perbandingan terhadap kinerja aktual produk. Beberapa pakar mengidentifikasi tiga macam pendekatan dalam mengonseptualisasikan harapan prapembelian atas kinerja produk (Tjiptono, 2006). Kepuasan adalah suatu fungsi dari perbedaan antara penampilan yang dirasakan dan diharapkan. Kepuasan 
pasien adalah tingkat kepusan dari persepsi pasien dan keluarga terhadap pelayanan kesehatan dan merupakan salah satu indikator kinerja rumah sakit. Bila pasien menunjukkan hal-hal yang bagus mengenai pelayanan kesehatan terutama pelayanan keperawatan dan pasien mengindikasikan dengan perilaku positifnya, maka dapat kita tarik kesimpulan bahwa pasien memang puas terhadap pelayanan tersebut (Purnomo, 2002).

Sesuai dengan teori diatas, nampak bahwa mutu pelayanan kebidanan memiliki hubungan dengan kepuasan pasien, hal ini berarti semakin baik mutu layanan yang diberikan maka semakin tinggi kepuasan pasien sehingga akan tercipta loyalitas pasien. Budaya kerja bidan di BPM secara umum yang masih berorientasi kepada cakupan layanan kadang kala mendorong bidan kurang memperhatikan kepuasan pasien, paradigma tersebut sebaiknya mulai digeser menuju budaya kerja yang lebih profesional dengan mempertimbangkan kepuasan dari sisi perspektif pasien. Secara umum nampak bahwa menurut perspektif pasien mutu layanan yang diberikan sudah cukup baik. Kondisi ini terkait dengan beberapa hal yang berkaitan dengan pola pelayanan di BPM, misalnya terkait dengan jam kerja dan empati yang ditunjukkan oleh bidan. Penelitian yang dilakukan Yuniarti (2009), masyarakat perkotaan beranggapan bahwa bidan memiliki empati yang lebih baik dibandingkan tenaga kesehatan lainnya. Empati yang ditunjukkan oleh bidan kebanyakan mencerminkan 3 aspek yaitu kepedulian, kehangatan dan kelembutan. Bidan sebagai tenaga kesehatan juga merupakan tokoh masyarakat pada suatu desa, posisi ini memberikan konsekuensi pada bidan untuk selalu perduli pada masyarakat dalam wilayah kerjanya, khususnya pada sasaran program yang menjadi tanggung jawabnya, yang akan menjadi obyek tindakannya. Kepedulian oleh bidan ditunjukkan dengan sikap yang dimiliki 
untuk memberikan perhatian terhadap sesama maupun lingkungan sekitarnya.

Bidan dalam melaksanakan tugasnya dituntut untuk memahami permasalahan yang dihadapi dan kondisi psikis masingmasing pasien yang menjadi tanggung jawabnya. Kepedulian ini terbentuk bukan hanya karena pasien merupakan salah satu sumber pendapatan bagi bidan, namun karena interaksi sosial pada masyarakat desa yang masih sangat kental. Kepedulian ini dapat mendorong dan memotivasi pasien untuk hadir kembali dalam pemeriksaan berikutnya. Hal ini juga tidak terlepas dari kematangan emosi yang dimiliki oleh bidan. Kematangan emosi bidan dalam memberikan pelayanan dapat mendorong bidan lebih sabar dalam mendengarkan keluhan pasien dan memberikan saran-saran yang masuk akal bagi pasien. Proses interaksi antara bidan dengan masyarakat pedesaan menempatkan bidan sebagai kaum intelektual yang harus dapat membimbing masyarakat menuju kesejahteraan, khususnya dari sudut pandang kesehatan.

Kondisi ini seringkali menempatkan bidan dalam posisi bukan hanya sebagai tenaga kesehatan sehatan namun juga sebagai konselor sosial. Keadaan inilah yang mendorong munculnya kematangan emosi pada bidan yang dapat dipergunakan sebagai dasar untuk melaksanakan pelayanan kebidanan dan kesehatan reproduksi.

Issak (2011) menyatakan bahwa dalam memberikan pelayanan pada komunitas bidan lebih bisa diterima dan dapat memahami permasalahan kesehatan masyarakat dengan lebih baik. Kepuasan pasien pasien merupakan satu elemen yang penting dalam mengevaluasi kualitas layanan dengan mengukur sejauh mana respon pasien setelah menerima jasa. Dengan adanya kualitas pelayanan yang baik di dalam pelayanan, akan menciptakan kepuasan bagi para pasien. Kepuasan yang ditunjukkan oleh pasien dalam pelaksanaan pemeriksaan, yaitu reaksi pasien terhadap pelayanan yang 
diterima dan ditinjau berdasarkan pengalaman yang dialami. Selain itu, kepuasan juga mempertimbangkan tentang apa yang dirasakan oleh pasien dalam pelaksanaan Tuntutan pasien akan mutu pelayanan mengharuskan adanya perubahan pelayanan dari paradigma lama ke paradigma baru. Kebutuhan pasien dalam menerima jasa pelayanan kesehatan yang diutamakan sehingga pasien merasa terpuaskan akan setiap pelayanan yang mereka terima dan kemudian dari kepuasan itu lahirlah sebuah loyalitas kepada BPM yang bersangkutan. Masyarakat akan melakukan sebuah tindakan, yang mereka pandang memberikan kepuasan yang maksimal bagi mereka. Itu alasannya setiap bidan sebagai pemberi layanan kesehatan di dalam masyrakat hendaknya berorientasi pada kepuasan pasien dalam pelaksanaan pemeriksaan dan tindakan untuk dapat meningkatkan kepatuhan pasien dalam melaksanaakan. Pasien yang akan merasa puas apabila ada persamaan antara harapan dan kenyataan pelayanan kesehatan yang diperoleh. Kepuasaan pengguna pelayanan kesehatan mempunyai kaitan yang erat dengan hasil pelayanan kesehatan, baik secara medis maupun non medis seperti kepatuhan terhadap terapi dan jadwal pelaksanaan pemeriksaan berikutnya.

\section{Kesimpulan Dan Saran}

\section{Kesimpulan:}

1. Jenis pelayanan yang diberikan oleh semua $\mathrm{BPM}: \mathrm{KB}$, pemeriksaan kehamilan, persalinan, imunisasi, periksa anak sakit (diare, batuk \& pilek). Pelayanan laboratorium yang diberikan : Uji HB menggunakan Test Pack dan $\mathrm{Hb}$ Sahli, Tes Kehamilan Menggunakan Test Pack dan Tes HIV sesuai dengan standar. Pelayanan yang diberikan oleh bidan sudah sesuai dengan standar, diawali dengan pemberian informasi dan diakhiri dengan pemberian penyuluhan. Semua bidan melakukan SOP dari IBI dan tidak ada SOP 
khusus. Peralatan yang Implikasi

dipergunakan oleh semua bidan

yang diteliti adalah standar dan tidak

ada modifikasi.

1. Implikasi Teoritis

Hasil penelitian ini menunjukkan perlunya penelitian lanjutan untuk

2. Mutu pelayanan yang diberikan oleh BPM telah memenuhi 4 dimensi mutu layanan dengan baik yaitu reliability, responsiveness, empathy dan assurance, sedangkan pada dimensi tangible masih membutuhkan perbaikan.

3. Pelayanan di BPM cepat, tepat dan bidan sangat ramah serta sangat peduli terhadap kliennya. Seluruh informan merasa puas, dan pelayanan bidan dipersepsikan lebih baik daripada pelayanan di rumah sakit. Harapan informan, BPM dapat meningkatkan sarana pendukung seperti parkir dan pendingin ruangan. mengetahui penyebab tingginya AKI di Surabaya karena segi pelayanan BPM sudah cukup baik.

2. Implikasi Manajerial

Hasil penelitian ini menunjukkan bagi pemegang kebijakan untuk memberikan dukungan yang lebih besar kepada BPM karena dalam penelitian ini terungkap BPM dapat memberikan pelayanan sesuai standar dan memenuhi harapan masyarakat.

Saran

1. Bagi Dinas Kesehatan Diharapkan dapat mendorong BPM dapat meningkatkan kualitas pelayanannya dan meningkatkan perannya dalam memberikan 
pelayanan maternitas sehingga

dapat mendorong penurunan AKI.

\section{Bagi BPM}

Diharapkan dapat mengembangkan

kualitas pelayanan khususnya

penyediaan sarana pendukung

sehingga dapat meningkatkan daya

saing BPM.

3. Bagi Peneliti Selanjutnya

Diharapkan dapat mengembangkan

penelitian ini khususnya dalam

mengungkap dimensi assurance

dalam pelayanan BPM yang tidak

terungkap dalam penelitian ini.

\section{DAFTAR PUSTAKA}

Dinas Kesehatan Kota Surabaya, 2013 Surabaya Dalam Angka
2013. Surabaya: Dinas Kesehatan

Kota Surabaya

Mas.ud, Fuad. 2004. Survai Diagnosis Organisasional Konsep \& Aplikasi. Semarang: Badan Penerbit Universitas Diponegoro. Semarang.

Santoso 2004. Analisis Pengaruh Kualitas Pelayanan Terhadap Kepuasan Pasien Rawat Inap Kelas III Pada RS. Roemani Muhammadiyah Semarang. Semarang:

Jurnal Fakultas Ekonomi Universitas Diponegoro

Syafruddin.2009. Organisasi dan Manajemen Pelayanan Kesehatan dalam Kebidanan. Jakarta: Trans Info Media

Tjiptono,Fandi.2000. Manajemen Jasa.

Yogyakarta: Penerbit Andi Offset

Tjiptono,Fandy, 2006,Manajemen Pelayanan Jasa.Yogyakarta:Penerbit Andi.

UU No 36 tahun 2009. Undang-Undang Republik Indonesia Nomor 36 tahu 